ENTREPRENEURSHIP AND SUSTAINABILITY ISSUES

ISSN 2345-0282 (online) http://jssidoi.org/jesi/

2020 Volume 8 Number 2 (December)

http://doi.org/10.9770/jesi.2020.8.2(12)

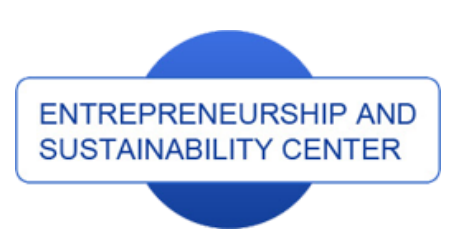

Publisher

http://jssidoi.org/esc/home

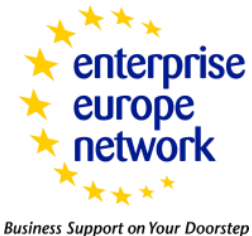

\title{
ROLE OF EDUCATION AND ECONOMIC GROWTH ON THE CO 2 EMISSIONS IN SAUDI ARABIA
}

\author{
Tarek Tawfik Yousef Alkhateeb ${ }^{1}$, Haider Mahmood ${ }^{2}$, Nouf Naser Altamimi ${ }^{3}$, Maham Furqan ${ }^{4}$ \\ ${ }^{1,2}$ College of Business Administration, Prince Sattam bin Abdulaziz University, 173 Alkharj 11942, Saudi Arabia \\ ${ }^{1}$ Kafr Elshiekh University, Kafr Elshiekh 33511, Egypt \\ ${ }^{3}$ Foundations of Education, Prince Sattam bin Abdulaziz University, Sa'ad Ibn Mu'adh, Al-Kharj 16278, Saudi Arabia \\ ${ }^{4}$ Oregon State University, Corvallis, OR 97331, United States
}

E-mails:, ${ }^{1,2}$ tkhteb@yahoo.com ; ${ }^{1}$ haidermahmood@hotmail.com; ${ }^{3}$ nn.altamimi@psau.edu.sa ; ${ }^{4}$ mahamfurqan@ymail.com

Received 18 March 2020; accepted 10 August 2020; published 30 December 2020

\begin{abstract}
Education can play an effective role in building social responsibility in a community which can help to reduce pollution emissions. This present research investigates the effects of education, energy consumption and economic growth on $\mathrm{CO}_{2} \mathrm{emissions}$ in Saudi Arabia using data of a period 1971-2014. We find that primary education could not affect $\mathrm{CO}_{2}$ emissions, but, secondary education has a negative effect while energy consumption has a positive effect on $\mathrm{CO}_{2}$ emissions. In the long run, an inverted U-shaped relationship is found between $\mathrm{CO}_{2}$ emissions and economic growth and Kingdom is found at first stage. Hence, economic growth is responsible for environmental degradation. We recommend to enhance the secondary education to improve the environment of the Kingdom and to use cleaner source of energy to avoid negative environmental consequences of economic growth.
\end{abstract}

Keywords: Education; Economic growth; Energy consumption; $\mathrm{CO}_{2}$ emissions

Reference to this paper should be made as follows: Alkhateeb, T.T.Y., Mahmood, H., Altamimi, N.N., Furqan, M. 2020. Role of education and economic growth on the CO2 emissions in Saudi Arabia. Entrepreneurship and Sustainability Issues, 8(2), $195-209$. http://doi.org/10.9770/jesi.2020.8.2(12)

JEL Classifications: O44, H75, K32 


\section{ENTREPRENEURSHIP AND SUSTAINABILITY ISSUES}

ISSN 2345-0282 (online) http://jssidoi.org/jesi/

2020 Volume 8 Number 2 (December)

http://doi.org/10.9770/jesi.2020.8.2(12)

\section{Introduction}

The idea of environmental stability and eco-friendly economic activities has been a hot topic of debate across the world. Many countries from the developed, developing, and under-developed parts of the world are making an effort so they can identify better and smarter ways to be more sustainable. Greenhouse gases are in the middle of the discussion of environmental talks and debates since it is one of the biggest causes of environmental degradation. One aspect of this endless discussion of the determinants of pollution emissions is the contribution that education and human capital may play in this domain. The level of education can help improve the economic condition of any economy while it also raises environmental awareness among the common people. On the other hand, considering that the EKC exists in a country, there is a need to expedite the process of economic growth so that the country can reach the cut off from where the environmentally degrading effects of economic activities start to decline and the ecological footprint starts to recover. In that instance, if education can improve the economic condition of a country which eventually reduces pollution, it can be easily said that education can be used as a major source of reducing pollution in a country.

The idea of the environmental Kuznets curve (EKC) is popular in the field of environment and energy as well and the concepts argue about the inverted U-shaped relationship between environment and growth (Grossman and Krueger, 1991). It means that economic growth pollutes the environment in the first phase of EKC. In the second stage, demand for a cleaner environment may increase with further economic growth. Theoretically speaking, the idea of this sort of a relationship does make sense because in many cases, as a country makes economic progress, it has to rely on a lot of energy consumptions at the first stage of development, most of which have to do with the industrial, construction and manufacturing sector. All of these developmental activities may increase $\mathrm{CO}_{2}$ emissions and pollute the environment due to higher energy consumption. Something similar was provided in a study by Eluwole et al. (2020) in which they mentioned that a 1\% increase in $\mathrm{kg}$ oil equivalent of energy consumed can increase environmental degradation by $0.918 \%$.

On the other hand, Bekun et al. (2019) mentioned that renewable energy consumption can lead to an improvement in environmental quality and fossil fuel can lead to deterioration in the environmental portfolio of a country. Alola et al. (2019) investigated the sixteen coastline Mediterranean countries using data 1995-2014 and found the bidirectional causality between renewable energy and $\mathrm{CO}_{2}$ emissions and between food production and $\mathrm{CO}_{2}$ emissions. They concluded that food production contributed to environmental degradation and inflation helped to reduce $\mathrm{CO}_{2}$ emissions. Moreover, Alola (2019) investigated the effects of the policies on the $\mathrm{CO}_{2}$ emissions in the US using quarterly data of 1990-2018. He found the positive effects of income, renewable energy consumption, trade policy, financial regulation, and monetary policy on the $\mathrm{CO}_{2}$ emissions in both the long and short run. However, the effect of migration policy is found insignificant. Mahmood et al. (2019) found the asymmetrical effects of trade openness on the $\mathrm{CO}_{2}$ emissions and increasing trade openness contributed to the $\mathrm{CO}_{2}$ emissions but the effect of decreasing trade openness is found insignificant.

There is limited research on whether education has to play a role in EKC or not. Balaguer and Cantavella (2018) argued that the energy resources of a country depend on the human capital and educational systems a lot and education can play a significant role in an economy on many levels. With an expansion on the EKC, the study investigated data from 1950-2014 and it was hypothesized that a higher educational level can offset the negative effects of $\mathrm{CO}_{2}$ emissions in the economy. They provided evidence that an increased level of education could offset the environmentally degrading effects of $\mathrm{CO}_{2}$ emissions. It proves that an expansion in the educational system can compensate for $\mathrm{CO}_{2}$ emissions that have resulted from income growth. It was suggested that since income growth is not as easy to manage, promoting education is always a good idea since the environmentally- 


\section{ENTREPRENEURSHIP AND SUSTAINABILITY ISSUES}

ISSN 2345-0282 (online) http://jssidoi.org/jesi/

2020 Volume 8 Number 2 (December)

http://doi.org/10.9770/jesi.2020.8.2(12)

degrading effects of economic activities can then be offset without having to make things worse in the first place. With education making its way up with economic growth, sustainable environmental objectives can be met without having to enforce a stringent environmental policy.

There is a limited number of studies that analyze the relationship of various educational levels on the environment while testing other economic variables. The EKC is well investigated in the Saudi environment literature (Omri et al., 2019; Mahmood et al., 2018; Mahmood et al., 2019) but a role of education on the $\mathrm{CO}_{2}$ emissions is still missing in the Saudi literature particularly. Ignoring the EKC, Mahmood et al. (2020) found that oil, non-oil income, and urbanization were increased the $\mathrm{CO}_{2}$ emissions in Saudi Arabia while gasoline prices helped to reduce emissions. Although, Omri et al. (2019) have probed the role of human development on $\mathrm{CO}_{2}$ emissions in Saudi Arabia and found an insignificant effect. Human development carries health, education, and income indicators. In which, education looks more meaningful in determining the pollution than that of health and income indicators. Therefore, the purpose of our research is to isolate the effect of education on the $\mathrm{CO}_{2}$ emissions in Saudi Arabia ignoring other dimensions of human capital.

\section{Literature Review}

There is good literature on testing the EKC hypothesis in Saudi Arabia. For example, Mahmood et al. (2018) investigated EKC in Saudi Arabia and found that Saudi Arabia is found in the first phase of EKC. Further, they found that Financial Market Development (FMD) has asymmetrical effects on $\mathrm{CO}_{2}$ emissions, and reducing FMD can lead to environmental degradation. Moreover, a decline in energy consumption can reduce $\mathrm{CO}_{2}$ emissions. In another dimension, Mahmood et al. (2019) investigated the effects of the agriculture sector on the $\mathrm{CO}_{2}$ emissions of Saudi Arabia and also tested the EKC hypothesis using the period 1971-2014. They found the EKC in the testing but the turning point indicated that Saudi Arabia was in the first phase of EKC. They also found the inverted U-shaped relationship between agriculture development and $\mathrm{CO}_{2}$ emissions. However, the negative effect of the agriculture sector on $\mathrm{CO}_{2}$ emissions was corroborated. Hence, the agriculture sector showed a pleasant environmental effect in Saudi Arabia.

Omri et al. (2019) conducted a study on Saudi Arabia to answer two major questions; one is about the EKC and the other is analyzing the effect of trade openness, FMD, human development, and FDI on the environment. The analysis aimed to investigate one of the most crucial concepts in the field of environmental economics. It was concluded that FDI, trade openness, and per capita income play a role in environmental degradation in the Kingdom which means that a higher national income, more foreign investment, and open trade relations with the neighboring countries can lead to higher emissions and degrade the environment. But, the effect of human development is found statistically insignificant. The EKC was validated and they indicated that as the country makes more economic progress, the negative effects of this environmental degradation can be offset. Mahmood et al. (2020) found the positive impact of industrialization and urbanization on the $\mathrm{CO}_{2}$ emissions in Saudi Arabia. Alkhatlan et al. (2020) investigated the oil concentration effects in Saudi Arabia and found the negative impacts of exports and employment concentration on economic growth. Moreover, Alkhateeb and Mahmood (2020) explored and found that oil price was responsible for energy depletion in the GCC region with asymmetrical effects of magnitude. This relationship was also true in each country analysis and most of the effects were found elastic as well. Mahmood and Furqan (2020) investigated the role of oil rents on emissions. They found that oil rents have a U-shaped relationship with $\mathrm{N}_{2} \mathrm{O}$, Inverted-U-shaped relationships with $\mathrm{CH}_{4}$ emissions, and linear positive relationship with $\mathrm{CO}_{2}$ emissions.

Other than Saudi Arabia, some studies have also focused on the role of human capital in determining the environment. Zafar et al. (2019) put forward an argument that investment in the natural resources sector, human 


\section{ENTREPRENEURSHIP AND SUSTAINABILITY ISSUES}

ISSN 2345-0282 (online) http://jssidoi.org/jesi/ 2020 Volume 8 Number 2 (December) http://doi.org/10.9770/jesi.2020.8.2(12)

capital, and FDI were associated with an ecological footprint in the US using data from 1970-2015. They found that energy consumption due to income growth could lead to a positive effect on the ecological footprint which deteriorated the environment. Granger causality showed a bidirectional relationship between energy consumption and ecological footprint. A similar relationship was shown between ecological footprint and economic growth and ecological footprint and human capital as well. It was suggested that the country puts more investment in human capital so that natural resources can be used more efficiently and the ecological footprint of the country could improve with time. Ma et al. (2019) worked on China using period 1995-2015 and it was mentioned by that human capital had a long-run quadratic effect on the environmental regulations which indicated that with time, the effect of education on environmental policies could improve and help to improve the ecological footprint of the country. For the sustainable development of a country, it is crucial to incorporate the education sector and focus on human capital so that the effects can be widespread. Zamil et al. (2019) explored that trade openness and economic growth had a positive contribution to the $\mathrm{CO}_{2}$ emissions in Oman. Education is not only beneficial for the environment but has also been helpful to improve moral upbringing and to reduce social unrest (Furqan and Mahmood, 2020). Literature also signified the role of human capital and innovation to achieve sustainable development and sustainable competitive advantage (Pangarso et al., 2020; Prasetyo and Kistanti, 2020).

Yao et al. (2019) conducted a panel analysis of OECD countries to scrutinize the role of human capital on energy consumption using data 1965-2014. The results of the study provided a piece of evidence that human capital is responsible for reducing energy consumption by almost $16 \%$ which is a dramatic decline. They segregated the energy consumption matrix into two clean and dirty sections. It was shown that reduction of $17 \%$ of dirty energy consumption and up to almost $86 \%$ of clean energy consumption were associated with human capital and almost this much percentage of clean energy consumption could be improved with higher education and human capital investment as well. The results of their study suggested that countries focusing on reducing their energy consumption and making it sustainable should focus on investing in human capital. This is a win-win situation for any country since not only the natural resources can be saved, a higher level of human capital can result in economic growth which benefits the country for a long-term.

Ponce et al. (2019) analyzed the labor market returns and human capital investments and connected their role with the energy sector in an empirical study using the period 2010-2016. The labor income and educational sector were seen to play a significant role in shaping the behavior of people towards the energy and environmental sector. While poor environmental stance and policy were a result of multiple dynamics including lack of awareness and education could take a step further in helping different communities with changing their behaviors towards the sector so that overall household behavior could be changed. Using a period 1974-2014, Bano et al. (2018) found that human capital affected the $\mathrm{CO}_{2}$ emissions in Pakistan. Both variables seemed to share a long-term relationship. Looking at these variables through the perspective of economic growth, it was also argued that while human capital investment increased in the country, $\mathrm{CO}_{2}$ emissions could be reduced without having to give a push to economic growth. Both major variables also shared a two-way causal relationship in the long-run. Further, they argued that interactive learning environments could be used to improve the levels of understanding of the general public regarding $\mathrm{CO}_{2}$ emissions and accumulations in a region as it could help in conducted human-facilitated sessions that could raise awareness and could remove any barriers from the learning structure. Without having to implement a strong macroeconomic policy, just educating on a small scale could make a huge difference as well (Qudrat-Ullah and Kayal 2018).

There is limited literature available on the role of education on $\mathrm{CO}_{2}$ emissions. According to Shields (2019), higher education can be strongly linked to global climate change. International student mobility was considered as a major determinant of greenhouse gas emissions on an international level. The results indicated that although global $\mathrm{CO}_{2}$ emissions across the world are experiencing some significantly large increase emissions per 


\section{ENTREPRENEURSHIP AND SUSTAINABILITY ISSUES}

ISSN 2345-0282 (online) http://jssidoi.org/jesi/ 2020 Volume 8 Number 2 (December) http://doi.org/10.9770/jesi.2020.8.2(12)

international student have declined which is explained by changes in student mobility patterns. In a theoretical setting, the fact cannot be denied that higher education can lead to changes in the economic and social structure of a community. As a result, other segments in the region can also improve which is something that needs to be considered while devising educational policies related to higher education of international students. Taylor et al. (2007) mentioned in their study that in commercial areas, educational campaigns helped to reduce storm-water pollution to a wide extent. Although the study did not connect education to $\mathrm{CO}_{2}$ emissions through economic growth, it was argued that higher education activities and more awareness campaigns helped to play a role in reducing pollution which magnified the importance of improving human capital and knowledge management platforms. On a practical level, countries aiming to reduce their ecological footprint should focus on educational activities more often so that they can cover some part of the pursuit through these initiatives.

Bekaroo et al. (2019) provided a unique talk on the topic of education, income growth, and their link with $\mathrm{CO}_{2}$ emissions. They argued that sustainability change agents of higher education institutions could have the responsibility of using the platform to raise this issue among the student community. In that instance, teachers in these higher educational institutions could spread awareness in the student community and inform them about the harmful effects of these pollutants. If conducted on a long-run basis, this conversation could become a major reason for a structural change in a country and could directly influence the environment. The study took place in Mauritius and data from 440 employees of higher educational institutions was used. The results suggested implementing strong policies that could help to incorporate the educational sector in the environmental policy to a more prominent extent.

One aspect of human capital is health and some studies worked on the effect of health variables on pollution emissions. For example, Chaabouni and Saidi (2017) analyzed 51 countries to explore the association between $\mathrm{CO}_{2}$ emissions, health spending, and income growth. Three groups of countries were selected according to income classification and data from 1995-2013 were used. A causal relationship was explored between the three variables under analysis. Additionally, unidirectional causality was also seen from $\mathrm{CO}_{2}$ emissions to health spending levels in all countries except low-income ones. It was suggested that these countries focus on energy consumption and productivity, and also the efficiency of energy since it provides more pathways for long-term growth and can help to create a good balance. Alola and Kirikkaleli (2019) analyzed the relationship between environmental quality and renewable consumption while the concept of immigration, consumption, and healthcare was also considered. The rich analysis studied the long and short-term relationship between $\mathrm{CO}_{2}$ emissions with the factors mentioned above. It was seen that immigration and healthcare sector amendments lead to higher $\mathrm{CO}_{2}$ emissions in the US. Further, Alola (2019) mentioned that renewable energy consumption and real income in a country put an impact on the carbon emissions of the country but health has an insignificant effect.

The recent literature signifies the importance of education, human capital, and human development in determining pollution emissions. Most of the literature on this issue focuses on the role of human capital and human development on pollution emissions which are composite of education, health, and income growth indicators. The testing of the isolated role of education is scant in global literature and absent in Saudi literature. So, this present research is trying to fill this gap.

\section{Theoretical framework}

The expected inverted U-shaped relationship of income growth and pollutants' emissions, which is known as the EKC hypothesis, is initiated by Grossman and Krueger (1991). It is hypothesized because economic growth requires intense energy consumption during the first stage of development to serve the increasing economic activities which are called scale effects which may be responsible for pollution emissions. Afterward, a clean 


\section{ENTREPRENEURSHIP AND SUSTAINABILITY ISSUES}

ISSN 2345-0282 (online) http://jssidoi.org/jesi/

2020 Volume 8 Number 2 (December)

http://doi.org/10.9770/jesi.2020.8.2(12)

environment may also be desired at the second stage of development which may by adopting clean technologies or diversify the economy from dirty industry to clean industry which is termed as technique and composition effects. Here, energy consumption plays an important role in shaping the EKC. Although the main idea of EKC advocates an inverted U-shaped relationship between economic growth and $\mathrm{CO}_{2}$ emissions, some recent studies argue on a different point of view (Mahmood et al. 2019).

Yang et al. (2015) argued in their study that there is no universal model here that can fit all economies in the world. Other than an inverted U-shape, inverted-N and $\mathrm{M}$ shapes may be found in the relationship between income and pollutants' emissions. These results can vary depending on the economic development of a country and how it varies based on the part of the world the country falls in. Li et al. (2019) argued that there is an inconsistency in the nexus between economic growth and $\mathrm{CO}_{2}$ emissions and mentioned that this relationship has an evolutionary nature that can be affected by time, geography, and socioeconomic aspects of a country. Other than an inverted $\mathrm{U}$-shaped curve, both inverted $\mathrm{N}$ and $\mathrm{M}$-shaped relationship can vary in different periods. Alkhateeb and Mahmood (2019) found the positive effect of trade openness on energy consumption. Moutinho et al. (2017) tested the existence of EKC in Portuguese and Spanish economies and provided evidence of an inverted $\mathrm{N}$-shaped EKC. It was narrated that promoting renewable energy in the economies can help to meet urgent goals while the benefits can go a long way. The relationship of the environment and income was tested in six nucleargenerating countries and it was mentioned that nuclear energy has proven to be beneficial for the environment while income can be favorable for the environment in some instances. Nevertheless, both income and $\mathrm{CO}_{2}$ emissions are determined on a simultaneous basis (Baek and Pride 2014).

Education may play a significant role in tracing the EKC because educated people's preference over clean energy consumption is different from un-educated people. Therefore, education is also a very important variable to regress in any pollution model which is ignored in most of the past literature. From the perspective of economics, education is considered to be a major investment in enhancing the social structure of a community. Its results might not show up immediately since it takes a couple of years for a generation to get educated. However, the long-term results of education cannot be ignored as it delivers more awareness in society and improves social responsibility (Jankal and Jankalove, 2017).

United Nations General Assembly (UNGA) adopted the 2030 Agenda according to which, sustainable development would be planned for the nations, and the agenda was called "Transforming Our World: The 2030 Agenda for Sustainable Development". The purpose of the 17 goals provided under the agenda is to ensure that three major dimensions are integrated including economic, social, and environmental segments. For education, the agenda is to ensure primary education and enable learners to acquire knowledge and skills that can help them to achieve sustainable growth and the agenda is to be achieved by 2030 (UNESCO, 2015). Education is responsible for spreading awareness and can help ensure long-term and sustainable growth (Ergen and Ergen, 2011). With primary education, misconceptions and prejudice can be removed from the societies and social responsibility can improve in communities (Jankal and Jankalove, 2017).

Recent literature has also discussed the role of education in determining energy consumption (World Bank, 2019). Some stream of recent literature also investigates the direct role of education in the pollution emissions and ecological footprints (Balaguer and Cantavella, 2018; Zafar et al., 2019; Ma et al., 2019; Bano et al., 2018). Balaguer and Cantavella (2018) argued that education may contribute to pollution emissions as educated people tend to have better income levels and demand more energy consumption items. On the other hand, education can boost social awareness which may demand clean technologies to reduce pollution emissions. Zafar et al. (2019) argued that human capital helps improve energy efficiency, adopt pollution-free technologies, and reducing fossilfuel energy use. Further, they also found that human capital remained helpful in reducing ecological footprints in 


\section{ENTREPRENEURSHIP AND SUSTAINABILITY ISSUES}

ISSN 2345-0282 (online) http://jssidoi.org/jesi/ 2020 Volume 8 Number 2 (December) http://doi.org/10.9770/jesi.2020.8.2(12)

the United States. Besides, Bano et al. (2018) argued that human capital removes pollution without harming economic growth. Moreover, Yao et al. (2019) reported that human capital is found helpful in reducing 15.36\% and $17.33 \%$ of total energy consumption and dirty energy consumption respectively in the OECD countries. Further, human capital is found useful in raising $85.54 \%$ of clean energy consumption. So, education level and human capital help reduce pollution emissions and shape the EKC as these are promoting clean energy.

\section{Methods}

Following the theory of EKC, we are hypothesizing the quadratic effects of economic growth on $\mathrm{CO}_{2}$ emissions. Further, literature also signifies that education and human capital are very important in determining the environmental behavior of educated people in the country. Most of the recent studies on the topic used the human capital or human development indices that capture the education, health, and income indicators (Zafar et al., 2019). But, our objective is to isolate the role of education on $\mathrm{CO}_{2}$ emissions. Balaguer and Cantavella (2018) hypothesized the role of higher education on $\mathrm{CO}_{2}$ emissions. But, higher education is obtained by a very limited proportion of the population and it provides specialized education, not the basic moral values. On the other hand, most of the population of any country is just benefited by primary and secondary education where basic moral values and ethics are communicated for personality development. This argument is also matched with the UNGA agenda to ensure at least a primary education for sustainable growth (UNESCO, 2015). Therefore, we are hypothesizing the two proxies of education in the $\mathrm{CO}_{2}$ emissions model i.e. primary and secondary education, and our model is as follows:

$$
C_{t}=f\left(Y_{t}, Y_{t}^{2}, P E_{t}, S E_{t}, E C_{t}\right)
$$

All variables in equation 1 are in natural logarithm and $t$ presents a maximum available sample period of 19712014. $C_{t}$ is $\mathrm{CO}_{2}$ emissions metric tons per capita. $Y_{t}$ is GDP per capita in constant (2010) US dollars which is a proxy of economic growth and $Y_{t}^{2}$ is square of $Y_{t} . E C_{t}$ is energy consumption $\mathrm{kg}$ of oil equivalent per capita. Data on $C_{t}, Y_{t}$, and $E C_{t}$ are sourced from World Bank (2019). $P E_{t}$ and $S E_{t}$ are primary and secondary school enrolment ratios respectively. Data on $P E_{t}$ and $S E_{t}$ are sourced from the Government of Saudi Arabia (2019). All utilized data are available in the appendix.

After the model's discussion, a general flow chart is provided in figure 1 to understand the mechanism of estimation. Figure 1 elaborates that we need to test the stationarity of the series at first. In case of level stationary series $\mathrm{I}(0)$ or first difference stationary series $\mathrm{I}(1)$ or a mix of $\mathrm{I}(0)$ and $\mathrm{I}(1)$, we may move towards the AutoRegressive Distributive Lag (ARDL) model because it is efficient in all of the mentioned cases due its bound testing procedure (Pesaran et al., 2001). After validation of cointegration, we may estimate the long and short-run elasticities.

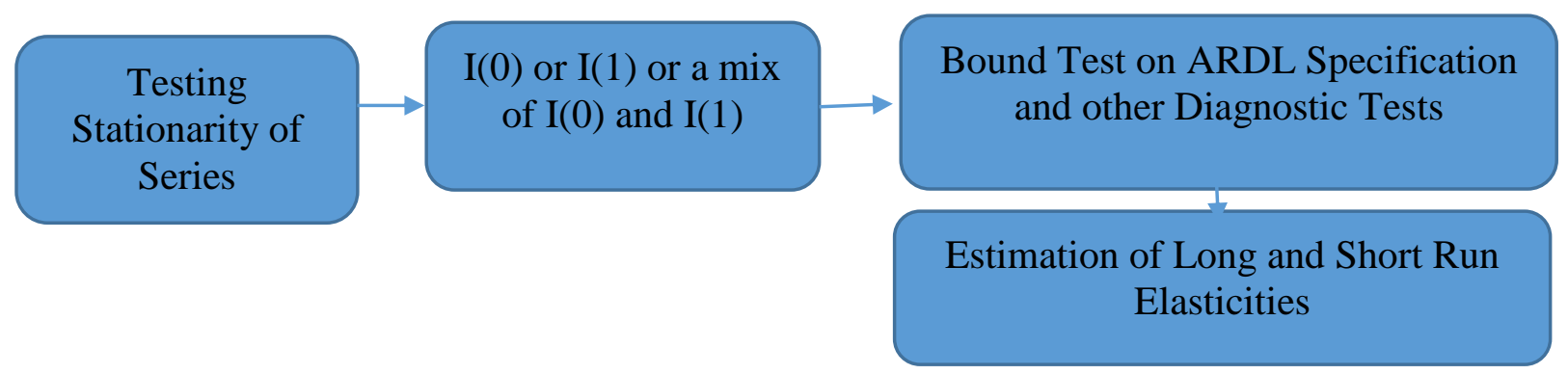

Figure 1. Flow Chart of Estimation 
To check the unit root problem in the series, we use $\mathrm{Ng}$ and Perron's (2003) methodology because of its superiority and efficiency over the other unit root test due to the de-trending procedure. Moreover, it utilized the four test statistics to confirm the stationarity in the series. After the stationarity test, we may shift our estimation towards the cointegration test. We choose ARDL of Pesaran et al. (2001) which is efficient over other cointegration tests due to its bound testing procedure. Moreover, its parsimonious way of selection of lag lengths also saves the degree of freedom. ARDL model of equation 1 may be expressed as:

$$
\begin{aligned}
& \Delta C_{t}=\alpha_{0}+\alpha_{1} C O_{t-1}+\alpha_{2} Y_{t-1}+\alpha_{3} Y_{t-1}^{2}+\alpha_{4} P E_{t-1}+\alpha_{5} S E_{t-1}+\alpha_{6} E C_{t-1} \\
& +\sum_{j=1}^{p} \beta_{1 j} \Delta C_{t-j}+\sum_{j=0}^{q} \beta_{2 j} \Delta Y_{t-j}+\sum_{j=0}^{r} \beta_{3 j} \Delta Y_{t-j}^{2}++\sum_{j=1}^{p} \beta_{4 j} \Delta P E_{t-j} \\
& +\sum_{j=0}^{q} \beta_{5 j} \Delta S E_{t-j}+\sum_{j=0}^{q} \beta_{6 j} \Delta E C_{t-j}+\psi_{i t}
\end{aligned}
$$

Equation 2 will be tested for the existence of cointegration on a null hypothesis $\alpha_{1}=\alpha_{2}=\alpha_{3}=\alpha_{4}=\alpha_{5}=\alpha_{6}=0$ and rejection of which would ensure the cointegration. Afterward, a diagnostic test of heteroscedasticity, serial correlation, normality of error term, and functional would be applied to ensure that estimates are out of econometric problems. Afterward, long-run effects could be calculated from normalizing procedure on the estimated $\alpha_{i}$. To capture the short-run elasticities, Error Correction Term $\left(E C T_{t-1}\right)$ may be replaced with the $\alpha_{1} C O_{t-1}+\alpha_{2} Y_{t-1}+\alpha_{3} Y_{t-1}^{2}+\alpha_{4} P E_{t-1}+\alpha_{5} S E_{t-1}+\alpha_{6} E C_{t-1}$ in the following way:

$$
\begin{aligned}
& \Delta C_{t}=\sum_{j=1}^{p} \delta_{1 j} \Delta C_{t-j}+\sum_{j=0}^{q} \delta_{2 j} \Delta Y_{t-j}+\sum_{j=0}^{r} \delta_{3 j} \Delta Y_{t-j}^{2}+\sum_{j=1}^{p} \delta_{4 j} \Delta P E_{t-j} \\
& +\sum_{j=0}^{q} \delta_{5 j} \Delta S E_{t-j}+\sum_{j=0}^{q} \delta_{6 j} \Delta E C_{t-j}+\gamma E C T_{t-1}+\zeta_{i t}
\end{aligned}
$$

In equation 3, negative and significant $\gamma$ would validate the existence of short-run relationships and speed of convergence and $\delta_{i j}$ may explain the short effects in the model.

\section{Data Analyses and Discussions}

At first, the Ng-Perron unit root test is applied to all series of our model assuming intercept and trend in analysis, and results are reported in table 1. Results show that all series except $S E_{t}$ are level non-stationary and $S E_{t}$ is stationary at a $1 \%$ level of significance. On their first difference, $C_{t}$ and $Y_{t}$ are stationary at 5\% and $P E_{t}$ and $E C_{t}$ are stationary at a $10 \%$ level of significance. Overall, $S E_{t}$ is level-stationary, and rest all variables are firstdifference stationery so mix integration level is substantiated. But, it is sufficient to proceed for the ARDL model as it chooses the lower-bound assuming level-stationery and upper-bound at first differenced-stationary variables (Pesaran et al., 2001). Therefore, the results of ARDL are efficient even in the presence of a mixed order of integration. 
Table 1. Unit Root Test

\begin{tabular}{|l|l|l|l|l|}
\hline Variable & $M Z a$ & $M Z t$ & $M S B$ & $M P T$ \\
\hline$C_{t}$ & $-11.9775(0)$ & -2.4356 & 0.2034 & 7.6703 \\
\hline$Y_{t}$ & $-3.3017(0)$ & -1.2130 & 0.3674 & 26.1391 \\
\hline$P E_{t}$ & $-1.5553(3)$ & -0.6381 & 0.4103 & 37.4287 \\
\hline$S E_{t}$ & $-28.1419(2)^{* * *}$ & $-3.5849^{* * *}$ & $0.1274^{* * *}$ & $4.1856^{* *}$ \\
\hline$E C_{t}$ & $-2.7809(0)$ & -1.1282 & 0.4057 & 31.1944 \\
\hline$\Delta C_{t}$ & $-0.7058(0)^{* *}$ & $-3.2054^{* *}$ & $0.1548^{* *}$ & $4.4746^{* *}$ \\
\hline$\Delta Y_{t}$ & $-17.9135(0)^{* *}$ & $-2.9801^{* *}$ & $0.1673^{* *}$ & $5.1414^{* *}$ \\
\hline$\Delta P E_{t}$ & $-14.3397(0)^{*}$ & $-2.6267^{*}$ & $0.1832^{*}$ & $6.6492^{*}$ \\
\hline$\Delta E C_{t}$ & $-15.3313(0)^{*}$ & $-2.7683^{*}$ & $0.1806^{*}$ & $5.9463^{*}$ \\
\hline
\end{tabular}

Note: *,** and $* * *$ are showing stationarity at $10 \%, 5 \%$ and $1 \%$ level of significance.

ARDL results of equations 2 and 3 are reported in table 2. At first, a bound test is applied to the ARDL equation, and the calculated F-value $=3.6317$ is found bigger than critical bound at a 5\% level of significance. The critical F-value is used from Kripfganz and Schneider (2018) which is also effective in case of a small sample size like in our case. Hence, a cointegration is corroborated in the model. Further, all diagnostic tests have p-values of more than 0.1 which validate that model has no issue of heteroscedasticity, serial correlation, functional form problem, and normality. Moreover, CUSUM and CUSUMsq tests' values are within critical bound at the bottom of the table, so estimated results are stable.

Table 2. ARDL Results

\begin{tabular}{|c|c|c|c|c|}
\hline Variables & Parameter & S.E. & $t$-value & $p$-value \\
\hline \multicolumn{5}{|c|}{ Long Run Results } \\
\hline$Y_{t}^{2}$ & -1.2326 & 0.5363 & -2.2982 & 0.0282 \\
\hline$S E_{t}$ & -0.1223 & 0.0408 & -2.9999 & 0.0052 \\
\hline$E C_{t}$ & 0.1820 & 0.0448 & 4.0665 & 0.0003 \\
\hline Intercept & -124.7060 & 53.8296 & -2.3167 & 0.0271 \\
\hline$\Delta Y_{t}^{2}$ & 0.1134 & 0.2460 & 0.4609 & 0.6480 \\
\hline$\Delta P E_{t}$ & -0.0956 & 0.2469 & -0.3871 & 0.7012 \\
\hline$\Delta S E_{t}$ & -1.0402 & 0.2260 & -4.6018 & 0.0001 \\
\hline$\Delta E C_{t}$ & 0.5895 & 0.1177 & 5.0099 & 0.0000 \\
\hline$E C T_{t-1}$ & -0.4514 & 0.0829 & -5.4434 & 0.0000 \\
\hline \multicolumn{5}{|l|}{ Diagnostics } \\
\hline F-Hetro & 1.3157 & & & 0.2642 \\
\hline$F$-Serial & 0.6827 & & & 0.5129 \\
\hline$F$-RESET & 0.0952 & & & 0.9535 \\
\hline$\chi^{2}$-Normality & 1.5357 & & & 0.2246 \\
\hline \multicolumn{3}{|l|}{ CUSUM Test } & \multicolumn{2}{|c|}{ CUSUMsq Test } \\
\hline
\end{tabular}




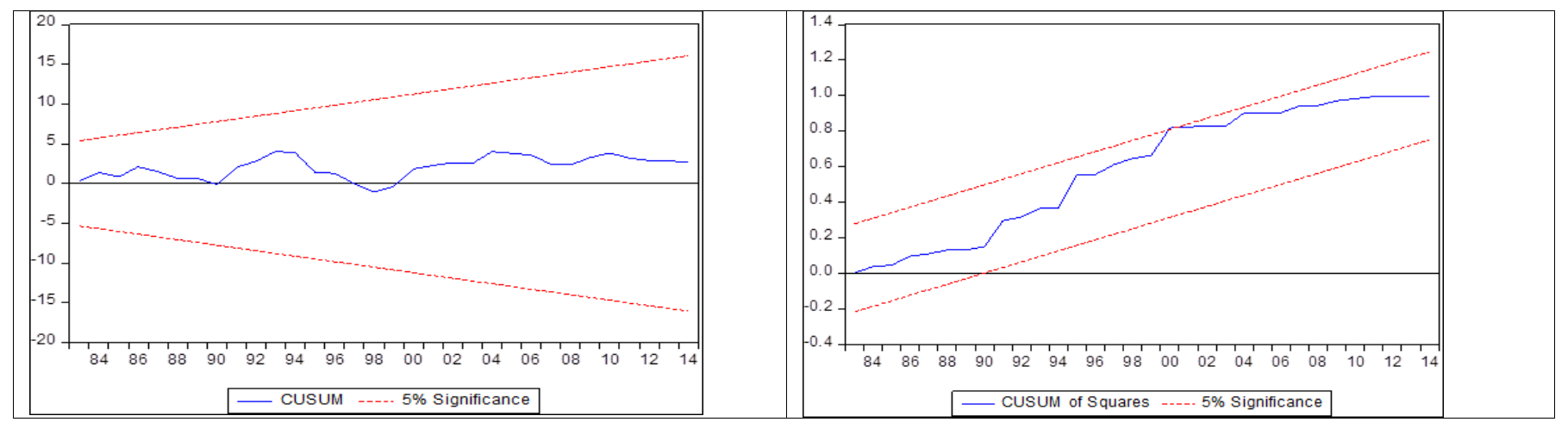

In the long run, $Y_{t}$ has a positive and $Y_{t}^{2}$ has a negative impact on $\mathrm{CO}_{2}$ emissions. This result is corroborating the existence of EKC in the Kingdom. Moreover, the turning point of the EKC (exponent of 24.9924/2.4652) is found at GDP per capita of 25290 constant US dollar which is more than the average sample period GDP per capita of 22900. Therefore, Saudi Arabia is found in the first stage of EKC, and increasing GDP per capita is responsible for increasing $\mathrm{CO}_{2}$ emissions. Therefore, economic growth has negative environmental effects by emitting $\mathrm{CO}_{2}$. This conclusion is matched with the findings of Mahmood et al. (2018) and Mahmood et al. (2019).

In the education and $\mathrm{CO}_{2}$ emissions relationship, primary education $\left(P E_{t}\right)$ has an insignificant impact on $\mathrm{CO}_{2}$ emissions. These results make sense because primary education is a very initial stage of human capital and individuals or even groups at this level do not have enough knowledge, understanding, or resources to do something about the environment. Due to the lack of ability of decision making, primary education alone cannot do enough to give someone exposure to the emissions and environmental portfolio of their country. So, primary education is not playing any of its positive or negative role in the environmental profile of Saudi Arabia. This can be due to a reason that education and age of students at the primary level are not mature enough to convey the message of environmental awareness. However, the government should revise the syllabus of primary education to convey the message of a clean environment at this level. Secondary education $\left(S E_{t}\right)$ has a negative and statistically significant effect. It means that increasing secondary education has pleasant environmental effects in terms of reducing $\mathrm{CO}_{2}$ emissions. Moreover, the elasticity coefficient of the $S E_{t}$ suggests that a $1 \%$ increase in $S E_{t}$ could reduce $0.1223 \%$ of $\mathrm{CO}_{2}$ emissions per capita.

This negative relationship between secondary education and $\mathrm{CO}_{2}$ emissions corroborates the finding of Balaguer and Cantavella (2018) who found that increasing levels of education would help reduce $\mathrm{CO}_{2}$ emissions. Further, Zafar et al. (2019) and Bano et al. (2018) also reported negative effects of human capital on the $\mathrm{CO}_{2}$ emissions and ecological footprint respectively. This leaves a huge room for improvement in the human capital policies in a country since that platform can be used to improve the energy sector to a wide extent. Considering the multidimensional nature of the energy sector, it is crucial to understand that not only the policies in the energy sector can make an impact; but any decisions taken in other sectors can have a strong impact on the segment as well. It must be taken into consideration that improving the education sector can go a long way, not only would the nation have a way more educated generation, but the environment would have improved as well which would be a winwin situation for the nation in the long-run. Lastly, energy consumption $\left(E C_{t}\right)$ has a positive impact on $\mathrm{CO}_{2}$ emissions and a $1 \%$ increase in $E C_{t}$ could increase by $0.182 \%$ of $\mathrm{CO}_{2}$ emissions.

In the short run, the negative and significant $\gamma$ of $E C T_{t-1}$ corroborates the short-run relationship in the model. Further, the magnitude $\gamma$ shows that short-run fluctuation could set back at a speed of $45.14 \%$ a year on the longrun path. Further, economic growth, its square, and primary education could not affect $\mathrm{CO}_{2}$ emissions. However, 


\section{ENTREPRENEURSHIP AND SUSTAINABILITY ISSUES}

ISSN 2345-0282 (online) http://jssidoi.org/jesi/

2020 Volume 8 Number 2 (December)

http://doi.org/10.9770/jesi.2020.8.2(12)

secondary education has again negative effect on the $\mathrm{CO}_{2}$ emissions with a relatively higher elasticity coefficient compare to the long-run result. A $1 \%$ increase in $S E_{t}$ could decrease the $1.0402 \%$ of $\mathrm{CO}_{2}$ emissions. Moreover, the energy consumption has a negative short-run effect on the $\mathrm{CO}_{2}$ emissions and a $1 \%$ increase in $E C_{t}$ may increase the $0.5895 \%$ of $\mathrm{CO}_{2}$ emissions.

\section{Conclusions}

Education may play a positive environmental role by reducing pollution emissions if education could enhance the social responsibility of the citizens. This present research tries to test the effects of primary and secondary education on the $\mathrm{CO}_{2}$ emissions along with testing the conventional determinants of $\mathrm{CO}_{2}$ emissions. We apply the ARDL cointegration test and use a period of 1971-2014 to investigate the said relationships. We found the cointegration in the hypothesized model and short-run relationships are also found with a speed of convergence, 45.14\% a year. We validate the EKC hypothesis in Saudi Arabia with a point of inflection at 25,290 GDP per capita. But, the kingdom is found at the first stage of $\mathrm{EKC}$ hence its economic growth is responsible for environmental degradation through emitting $\mathrm{CO}_{2}$. Further, the short-run effect of economic growth is found insignificant. The effect of primary education is found insignificant but increasing secondary education is found helpful in reducing $\mathrm{CO}_{2}$ emissions. Moreover, energy consumption is increasing $\mathrm{CO}_{2}$ emissions. Based on the results, we recommend the Kingdom to promote secondary education in the Kingdom to improve the awareness of the social responsibility of reducing pollution emissions and to use clean energy sources to remove the negative environmental effects of economic growth. Additionally, since it is mentioned that secondary education has an impact on the environment; there should be more efforts to take the educational system of the country up a notch to ensure that the segment provides positive results not only for the human capital but for the environment as well. This multi-disciplinary approach would be creative enough for the nation to move ahead and take serious actions to stop the environmental degradation in the country.

\section{References}

Alkhateeb, T.T.Y., Mahmood, H. (2019). Energy Consumption and Trade Openness Nexus in Egypt: Asymmetry Analysis. Energies 12(10): 2018. https://doi.org/10.3390/en12102018

Alkhateeb, T.T.Y., Mahmood, H. (2020). Oil Price and Energy Depletion Nexus in GCC countries: Asymmetry Analyses. Energies 13(12): 3058. https://doi.org/10.3390/en13123058

Alkhathlan, K.A., Alkhateeb, T.T.Y., Mahmood, H., Bindabel, W.A. (2020). The concentration of the oil sector or diversification in the Saudi economy: consequences on growth sustainability. Entrepreneurship and Sustainability Issues 7(4): 3369-3384. http://doi.org/10.9770/jesi.2020.7.4(52)

Alola, A. (2019). Carbon emissions and the trilemma of trade policy, migration policy and health care in the US. Carbon Management 10(2): 209-218. https://doi.org/10.1080/17583004.2019.1577180

Alola, A., Kirikkaleli, D. (2019). The nexus of environmental quality with renewable consumption, immigration, and healthcare in the US: Wavelet and Gradual-Shift causality approaches. Environmental Science and Pollution Research 26(34): 35208-35217. https://doi.org/10.1007/s11356-019-06522-y

Alola, A.A. (2019). The trilemma of trade, monetary and immigration policies in the United States: Accounting for environmental sustainability. Science of the Total Environment 658: 260-267. https://doi.org/10.1016/j.scitotenv.2018.12.212 


\section{ENTREPRENEURSHIP AND SUSTAINABILITY ISSUES}

ISSN 2345-0282 (online) http://jssidoi.org/jesi/ 2020 Volume 8 Number 2 (December)

http://doi.org/10.9770/jesi.2020.8.2(12)

Alola, A.A., Yalçiner, K., Alola, U.V. (2019) Renewables, food (in) security, and inflation regimes in the coastline Mediterranean countries (CMCs): the environmental pros and cons. Environmental Science and Pollution Research 26(33): 34448-34458. https://doi.org/10.1007/s11356-019-06576-y

Baek, J., Pride, D. (2014). On the income-nuclear energy- $\mathrm{CO}_{2}$ emissions nexus revisited. Energy Economics 43: 6-10. https://doi.org/10.1016/j.eneco.2014.01.015

Balaguer, J., Cantavella, M. (2018). The Role of Education in the Environmental Kuznets Curve, Evidence from Australian Data. Energy Economics 70(1): 289-296. https://doi.org/10.1016/j.eneco.2018.01.021

Bano, S., Zhao, Y., Ahmad, A., Wang, S., Liu, Y. (2018). Identifying the Impacts of Human Capital on Carbon Emissions in Pakistan. Journal of Cleaner Production 183: 1082-1092. https://doi.org/10.1016/j.jclepro.2018.02.008

Bekaroo, G., Bakhoree, C., Ramsamy, P., Moedeen, W. (2019). Investigating Personal Carbon Emissions of Employees of Higher Education Institutions: Insights from Mauritius. Journal of Cleaner Production 209: 581-594. https://doi.org/10.1016/j.jclepro.2018.10.238

Bekun, F., Alola, A., Sarkodie, S. (2019). Toward a sustainable environment: Nexus between $\mathrm{CO}_{2}$ emissions, resource rent, renewable and nonrenewable energy in 16-EU countries. Science of the Total Environment 657: 1023-1029. https://doi.org/10.1016/j.scitotenv.2018.12.104

Chaabouni, S., Saidi, K. (2017). The Dynamic Links Between Carbon Dioxide $\left(\mathrm{CO}_{2}\right)$ Emissions, Health Spending and GDP Growth: A Case Study for 51 Countries. Environmental Research 158(1): 137-144. https://doi.org/10.1016/j.envres.2017.05.041

Eluwole, K., Akadiri, S., Alola, A., Etokakpan, M. (2020). Does The Interaction between Growth Determinants a Drive for Global Environmental Sustainability? Evidence from World Top 10 Pollutant Emissions Countries. Science of the Total Environment 725: 1-8. https://doi.org/10.1016/j.scitotenv.2019.135972

Ergen, B., Ergen, Z. (2011). How Does Education Affect Environmental Knowledge: A Survey in Urban and Regional Planning Education. US-China Education Review 7: 924-931. https://eric.ed.gov/?id=ED529915

Furqan, M., Mahmood, H. (2020). Does Education Reduce Homicide? A Panel Data Analysis of Asian Region. Quality and Quantity 54(4): 1197-1209. https://doi.org/10.1007/s11135-020-00981-Z

Government of Saudi Arabia (2019). Yearly Statistics 2019, Saudi Arabian Monetary Agency, Riyadh. https://sama.gov.sa/enUS/EconomicReports/Pages/YearlyStatistics.aspx

Grossman, G.M., Krueger, A.B. (1991). Environmental impacts of the North American Free Trade Agreement. NBER, Working paper 3914. https://doi.org/10.3386/w3914

Jankal, R., Jankalove, M. (2017). Social Responsibility of the Educational Institution. Human Resources Management and Ergonomics 11(2): 51-58. https://doi.org/10.1007/978-981-10-5047-3

Kripfganz, S., Schneider, D.C. (2018). Response surface regressions for critical value bounds and approximate p-values in equilibrium correction models. Manuscript, University of Exeter and Max Planck Institute for Demographic Research. www.kripfganz.de

Li, W., Yang, G., Li, X. (2019). Modeling The Evolutionary Nexus Between Carbon Dioxide Emissions and Economic Growth. Journal of Cleaner Production 215: 1191-1202. https://doi.org/10.1016/j.jclepro.2019.01.100

Ma, S., Dai, J., Wen, H. (2019). The Influence of Trade Openness on the Level of Human Capital in China: On the Basis of Environmental Regulation. Journal of Cleaner Production 225(1): 340-349. https://doi.org/10.1016/j.jclepro.2019.03.238

Mahmood, H., Alkhateeb, T.T.Y., Al-Qahtani, M.M.Z., Allam, Z., Ahmad, N., Furqan, M. (2019). Agriculture Development and CO 2 Emissions Nexus in Saudi Arabia. PLoS ONE 14(12): e0225865. https://doi.org/10.1371/journal.pone.0225865

Mahmood, H., Alkhateeb, T.T.Y., Furqan, M. (2020). Oil Sector and $\mathrm{CO}_{2}$ Emissions in Saudi Arabia: Asymmetry Analysis. Palgrave Communications 6(1): 88. https://doi.org/10.1057/s41599-020-0470-z 


\section{ENTREPRENEURSHIP AND SUSTAINABILITY ISSUES}

ISSN 2345-0282 (online) http://jssidoi.org/jesi/

2020 Volume 8 Number 2 (December)

http://doi.org/10.9770/jesi.2020.8.2(12)

Mahmood, H., Alkhateeb, T.T.Y., Furqan, M. (2020). Industrialization, urbanization and $\mathrm{CO}_{2}$ emissions in Saudi Arabia: Asymmetry analysis. Energy Reports 6: 1553-1560. https://doi.org/10.1016/j.egyr.2020.06.004

Mahmood, H., Alrasheed, A., Furqan, M. (2018). Financial Market Development and Pollution Nexus in Saudi Arabia: Asymmetrical Analysis. Energies 11(12): 3462. https://doi.org/10.3390/en11123462

Mahmood, H., Furqan, M. (2020). Oil Rents and Greenhouse Gas Emissions: Spatial Analysis of Gulf Cooperation Council Countries. Environment, Development and Sustainability, https://doi.org/10.1007/s10668-020-00869-w

Mahmood, H., Furqan, M., Bagais, O.A. (2019). Environmental accounting of financial development and foreign investment: spatial analyses of East Asia. Sustainability 11(1): 0013. https://doi.org/10.3390/su11010013

Mahmood, H., Maalel, N., Zarrad, O. (2019). Trade Openness and $\mathrm{CO}_{2}$ Emissions: Evidence from Tunisia. Sustainability 11(12): 3295. $\underline{\text { https://doi.org/10.3390/su11123295 }}$

Moutinho, V., Varum, C., Madaleno, M. (2017). How Economic Growth Affects Emissions? An Investigation of the Environmental Kuznets Curve in Portuguese and Spanish Economic Activity Sectors. Energy Policy 106: 326-344. https://doi.org/10.1016/j.enpol.2017.03.069

Ng, S., Perron, P. (2003). Lag Length Selection and the Construction of Unit Root Tests with Good Size and Power. Econometrica 66: 1519-1554. https://doi.org/10.1111/1468-0262.00256

Omri, A., Euchi, J., Hasaballah, A., Al-Tit, A. (2019). Determinants of Environmental Sustainability: Evidence from Saudi Arabia. Science of the Total Environment 657(1): 1592-1601. https://doi.org/10.1016/j.scitotenv.2018.12.111

Pangarso, A., Astuti, E.S., Raharjo, K., Afrianty, T.W. (2020). The impact of absorptive capacity and innovation ambidexterity on sustainable competitive advantage: the case of Indonesian higher education. Entrepreneurship and Sustainability Issues 7(3): 2436-2455. https://doi.org/10.9770/jesi.2020.7.3(65)

Pesaran, M.H., Shin, Y., Smith, R.J. (2001). Structural analysis of vector error correction models with exogenous I(1) variables. Journal of Econometrics 97(2): 293-343. https://doi.org/10.1016/S0304-4076(99)00073-1

Ponce, P., Alvarado, R., Ponce, K., Alvarado, R., Granda, D., Yaguana, K. (2019). Green Returns of Labor Income and Human Capital: Empirical Evidence of the Environmental Behavior of Households in Developing Countries. Ecological Economics 160: 105-113. https://doi.org/10.1016/j.ecolecon.2019.02.012

Prasetyo, P.E., Kistanti, N.R. (2020). Human capital, institutional economics and entrepreneurship as a driver for quality \& sustainable economic growth. Entrepreneurship and Sustainability Issues 7(4): 2575-2589. https://doi.org/10.9770/jesi.2020.7.4(1)

Qudrat-Ullah, H., Kayal, A. (2018). How to Improve Learners' (MIS) Understanding of $\mathrm{CO}_{2}$ Accumulations through the Use of HumanFacilitated Interactive Learning Environments. Journal of Cleaner Production 184: 188-197. https://doi.org/10.1016/j.jclepro.2018.02.244

Shields, R. (2019). The Sustainability of International Higher Education: Student Mobility and Global Climate Change. Journal of Cleaner Production 217: 594-602. https://doi.org/10.1016/j.jclepro.2019.01.291

Taylor, A., Curnow, R., Fletcher, T., Lewis, J. (2007). Education Campaigns to Reduce Stormwater Pollution in Commercial Areas: Do They Work? Journal of Environmental Management 84: 323-335. https://doi.org/10.1016/j.jenvman.2006.06.002

UNESCO (2015). Unpacking Sustainable Development Goal 4 Education 2030. [Online] Available at: https://www.campaignforeducation.org/docs/post2015/SDG4.pdf [Accessed November 2019].

World Bank (2019). World Development Indicators. Washington, D.C.: The World Bank.

Yang, G., Sun, T., Wang, J., Li, X. (2015). Modeling The Nexus between Carbon Dioxide Emissions and Economic Growth. Energy Policy 86: 104-117. https://doi.org/10.1016/i.enpol.2015.06.031

Yao, Y., Ivanovski, K., Inekwe, J., Smyth, R. (2019). Human Capital and Energy Consumption: Evidence from OECD Countries. Energy Economics 84: 104534. https://doi.org/10.1016/j.eneco.2019.104534 
Zafar, M.W., Zaidi, S.A.H., Khan, N.R., Mirza, F.M., Hou, F., Kirmani, S.A.A. (2019). The Impact of Natural Resources, Human Capital, and Foreign Direct Investment on the Ecological Footprint: The Case of the United States. Resources Policy 63: 101-114. https://doi.org/10.1016/j.resourpol.2019.101428

Zamil, A.M.A., Furqan, M., Mahmood, H. (2019). Trade Openness and $\mathrm{CO}_{2}$ emissions nexus in Oman. Entrepreneurship and Sustainability Issues 7(2): 1319-1329. https://doi.org/10.9770/jesi.2019.7.2(36)

Appendix: Data utilized

\begin{tabular}{|c|c|c|c|c|}
\hline Years & $\mathrm{PE}$ & $\overline{\mathrm{SE}}$ & $\overline{\mathrm{EC}}$ & $\mathrm{Y}$ \\
\hline 1972 & 4.387549 & 1.436655 & 2.398055 & 10.30667 \\
\hline 1973 & 4.375846 & 1.51886 & 2.651105 & 10.47429 \\
\hline 1974 & 4.359959 & 1.619673 & 2.638635 & 10.57453 \\
\hline 1977 & 4.301127 & 1.930745 & 2.664198 & 10.5599 \\
\hline 1978 & 4.283999 & 2.023311 & 2.585083 & 10.45327 \\
\hline 1979 & 4.273786 & 2.053088 & 2.711252 & 10.50989 \\
\hline 1980 & 4.280612 & 2.050359 & 2.855986 & 10.50556 \\
\hline 1983 & 4.259132 & 2.187583 & 2.616691 & 9.928804 \\
\hline 1984 & 4.250684 & 2.210477 & 2.523505 & 9.821573 \\
\hline 1985 & 4.246009 & 2.233796 & 2.571894 & 9.663626 \\
\hline 1986 & 4.243823 & 2.247969 & 2.692762 & 9.770474 \\
\hline 1987 & 4.24539 & 2.263852 & 2.574816 & 9.655587 \\
\hline 1988 & 4.243145 & 2.306486 & 2.592662 & 9.736343 \\
\hline 1989 & 4.235018 & 2.332041 & 2.55962 & 9.692428 \\
\hline 1990 & 4.228099 & 2.359083 & 2.431879 & 9.798279 \\
\hline 1997 & 4.060385 & 2.809294 & 2.405685 & 9.830288 \\
\hline
\end{tabular}


ENTREPRENEURSHIP AND SUSTAINABILITY ISSUES

ISSN 2345-0282 (online) http://jssidoi.org/jesi/ 2020 Volume 8 Number 2 (December) http://doi.org/10.9770/jesi.2020.8.2(12)

\begin{tabular}{|c|c|c|c|c|}
\hline 1998 & 4.033969 & 2.869264 & 2.346163 & 9.839673 \\
\hline 1999 & 4.017015 & 2.910761 & 2.41222 & 9.780807 \\
\hline 2000 & 4.009868 & 2.942841 & 2.660279 & 9.812645 \\
\hline 2002 & 3.999587 & 2.992451 & 2.70137 & 9.718328 \\
\hline 2003 & 4.003101 & 3.019549 & 2.674773 & 9.795621 \\
\hline 2005 & 3.982669 & 3.09432 & 2.811437 & 9.868343 \\
\hline 2006 & 3.972123 & 3.092021 & 2.868271 & 9.868096 \\
\hline 2007 & 3.958102 & 3.110805 & 2.731505 & 9.859335 \\
\hline 2008 & 3.949648 & 3.133584 & 2.808378 & 9.893069 \\
\hline 2012 & 3.936774 & 3.186728 & 2.966278 & 9.954957 \\
\hline 2013 & 3.934316 & 3.199735 & 2.894162 & 9.952516 \\
\hline 2014 & 3.936171 & 3.17789 & 2.971914 & 9.960976 \\
\hline
\end{tabular}

Tarek Tawfik Yousef ALKHATEEB

ORCID ID: https://orcid.org/0000-0001-8215-9522

Haider MAHMOOD

ORCID ID: https://orcid.org/0000-0002-6474-4338

Maham FURQAN

ORCID ID: https://oricid.org/0000-0002-6275-5447

Make your research more visible, join the Twitter account of ENTREPRENEURSHIP AND SUSTAINABILITY ISSUES:

@Entrepr69728810

Copyright (C) 2020 by author(s) and VsI Entrepreneurship and Sustainability Center

This work is licensed under the Creative Commons Attribution International License (CC BY).

http://creativecommons.org/licenses/by/4.0/

(c) (i) Open Access 